\title{
PELATIHAN PEMBUATAN PUPUK ORGANIK CAIR BAGI GURU DAN SISWA SMAN O8 MATARAM
}

\author{
Hulyadi, Ahmadi, Yusran Khery, Husnul Hatimah, Dahlia Rosma Indah, Hendrawani \\ Program Studi Pendidikan Kimia, FSTT, UNDIKMA \\ Corresponding Author: hulyadi@ikipmataram.ac.id
}

\begin{abstract}
Abstrak : kegiatan pengabdian kepada masyarakat ini bertujuan untuk menambahkan kreativitas guru dalam melihat permasalahan lingkungan disekitar sekolah. Salah satu permasalahan yang dihadapi guru di SMAN 08 Mataram aroma tidak sedap dari limbah pengolahan tahu, limbah organik dari daun-daun pepohonan yang ada disekitar sekolah dan. Limbah cair yang terbuang secara langsung keparit sekitar sekolah menimbut aroma tidak enak. Aroma ini menyebabkan siswa terganggu dalam melakukan proses kegiatan belajar. Dibutuhkan teknologi untuk mengatasi masalah tersebut. Pengolahan limbah menjedi pupuk organik cair menjedi salah satu solusi untuk menjawab permasalahan tersebut. Pembuatan pupuk organik membutuhkan mikroorganisme untuk menguraikan bahan organik menjadi mineral yang lebih mudah diserap oleh tanaman. Metode kegiatan berupa pelatihan kemudian dilanjutkan dengan pembautan starter dari limbah buah dan bahan organik yang kaya dengan mineral yang ada dilingkungan sekitar sekolah. Berdasarkan hasil evaluasi guru dan siswa menunjukkan antusias yang besar terbukti semua siswa mengikuti kegiatan sampe selesai. Banyaknya pertanyaan dari guru dan siswa bagaimana aplikasinya lebih lanjutnya terhadap tanaman juga merupakan bukti ketertarikan guru dan siswa untuk mengaplikasikan pupuk yang akan dibuat. Guru dan siswa berharap kegitan ini bisa dilanjutkan proses pengabdian ini bisa diintegrasikan dalam pembelajaran IPA untuk mengsilkan proses pembelajaran yang lebih bermakna.
\end{abstract}

\section{Kata Kunci: Pelatihan Pembuatan Pupuk Organik Cair, Bagi Guru Dan Siswa}

\section{PENDAHULUAN}

Tahu dan tempe merupakan makanan yang sangat kaya dengan protein nabati, mineral dan vitamin. Makanan ini sangat disukai oleh masyarakat kalangan ekonomi kelas bawah sampai atas. Harga yang terjangkau, rasa enak serta tingginya nilai gizi yang terkandung menjadi alasan makanan ini menjadi primadona bagi masyarakat pada umumnya. Banyaknya peminat dan permintaan makanan ini menyebabkan industri rumahan tahu dan tempe menjamur di Nusa Tengara Barat Khususnya pulau Lombok. Pertumbuhan industri tahu dan tempe di NTB kususnya pulau Lombok sangat membantu prekonomian masyarakat. Berkembangnya industri tahu dan tempe belum diikuti oleh kemampuan mengatasi permasalahan limbah cair yang dihasilkan. Melimpahnya limbah cair yag dihasilkan pada proses produksi menjadi salah satu alasan pengolahan limbah cair tahu karena limbah cair tahu mengandung bahan - bahan organik yang masih sangat tinggi seperti karbohidrat, protein, lemak kalium dan sebagianya. Selain itu juga memiliki BOD dan COD yang cukup tinggi. (Nasir et al, 2015). Samapai saat ini limbah industri tahu tempe belum diolah. Limbah hanya dibuang kebadan air. Limbah yang kaya dengan bahan organik ini selanjut mengalami proses biokimia. Proses ini menyebabkan terbentuknya bahan yang berbahaya bagi lingkungan. Aroma yang tidak enak dari penguraian limbah ini sangat dikeluhkan oleh masyarakat.

Studi karateristik awal air buangan industri tahu yang dilakukan oleh Myrasandri dan Syafila (2009), zat organik yang terdapat pada limbah tahu memiliki kandungan yang melebihi baku mutu. Diantaranya adalah kandungan BOD sebesar $6586 \mathrm{mg} / \mathrm{l}$ dan COD sebesar $8640 \mathrm{mg} / \mathrm{l}$. Selain itu pada uji karakteristik awal limbah tahu yang dilakukan oleh Kaswinarni (2007), diperoleh hasil suhu air limbah tahu berkisar $37-45^{\circ} \mathrm{C}$, BOD sebesar 6.000-8.000 mg/1, dan COD sebesar 
7.500-14.000 mg/1. Dibandingkandengan baku mutu limbah cair industri tahu dan tempet.

Limbah cair tahu yang mengandung zat tersebut melebihi baku mutu dibiarkan mengalir ke badan air secara terus menerus maka akan mengganggu lingkungan yaitu timbulnya bau busuk dan kematian terhadap organisme air. Melihat dampak negetif yang ditimbulkan oleh limbah tahu sangat serius terhadap lingkungan diperlukan teknik pengolahan limbah yang tepat. Salah satu teknik pengolahannya adalah membuat limbah cair tahu menjadi pupuk organik cair (Sato, 2015). Penambahan mikroorgamisme pengurai senyawa organik makro molekul menjadi senyawa kimia yang lebih sederhana terbukti mampu menurunkan kadar COD limbah organik ( Tonni et al, 2010). Kadar N total, $\mathrm{P}$ dan $\mathrm{K}$ dalam air limbah tahu dicapai $43,37 \mathrm{mg} / \mathrm{L}, 114,36 \mathrm{mg} / \mathrm{L}$ dan $223 \mathrm{mg} / \mathrm{L}$ ( Kusumawati, 2015). Keberadaan beberapa elemen dalam air limbah industri tahu seperti $\mathrm{N}$, P, dan $\mathrm{K}$ dalam jumlah tertentu diperlukan oleh tanaman untuk pertumbuhannya (Sudarti, 2007).

SMAN 08 Mataram dilewati oleh aliran pembuangan limbah tempe dan tahu. Dihilir aliran air kesekolah terdapat sekitar 10 insdustri tahu dan tempe. Guru dan siswa mengeluhkan aroma limbahnya limbah tahu dan tempe mengularkan aroma tidak sedap karena penguraian limbah menjadi $\mathrm{NH}_{3}$ dan $\mathrm{H}_{2} \mathrm{~S}$. Kondisi ini harus diatasi supaya tercipta lingkungan pembelajaran yang aman dan nyaman.

Solusi yang ditawarkan kepada mitra terkait permasalahan di atas yaitu pengohan limbah tahu dan tempe menjadi pupuk organik cair. Limbah tahu yang kaya dengan protein, mineral makro dan mikro seperti kalium, pospor, carbon, dan kalsium sangat tepat untuk diolah menjadi pupuk organik cair. Limbah padat pengolahan tahu tidak menimbulkan masalah yang berarti bagi lingkungan karena dapat dimanfaatkan menjadi pakan ternak. Limbah cair yang perlu mendapatkan perhatian karena langsung dibuang kebadan air.

Pengolahan limbah cair tahu menjadi pupuk organik menjadi solusi yang tepat.
Desa danger terkenal dengan daerah pengasil sayur mayur. Pembuatan pupuk organik cair ini juga dapat dimanfaatkan diluar lingkungan sekolah. Luaran yang dihasilkan dalam kegiatan pengabdian ini dideskripsikan sebagai berikut.

1. Produk, berupa EM4 dari bahan organik dari lingkungan sekitar sekolah.

2. Produk Pupuk organik cair

\section{METODE PELAKSANAAN Teknik Pembuatan EM4.}

Sebelum pembuatan pupuk organik cair kita membutuhkan mikroorganisme pengurai bahan organik. Mikroorganisme pengurai berasal dari mikroba dan jamur yang biasanya disebut Effective Microorganism 4 (EM4). Tahapan pembuatan EM4 dari limbah buah dan bahan organik yang ada dilingkungan.

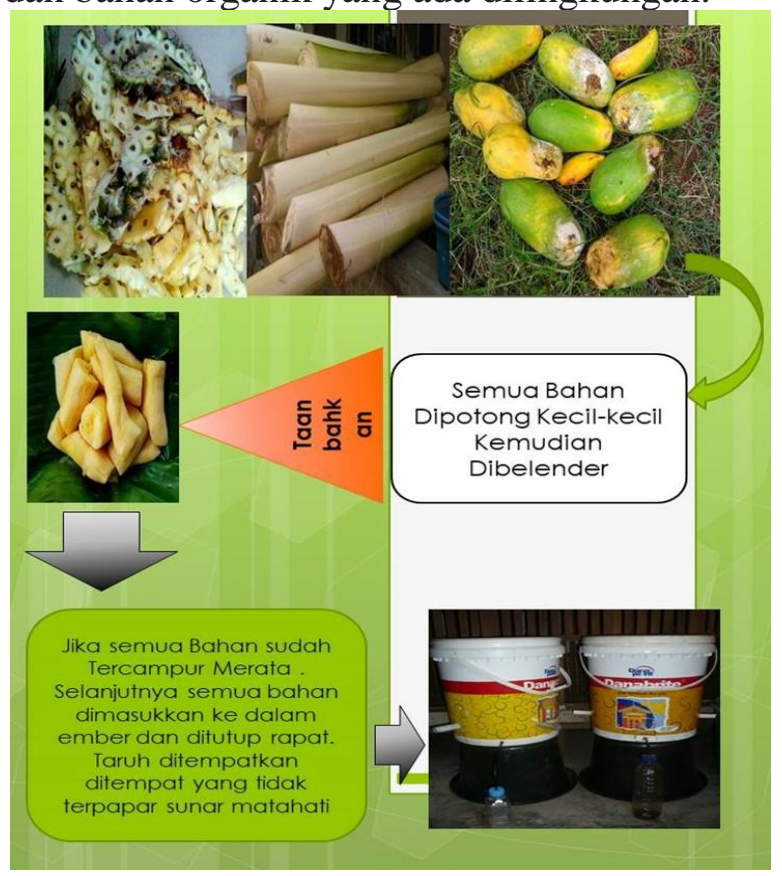

\section{Metode Pemecahan Masalah}

Kegiatan Pembuatan pupuk organik cair (POC) limbah tahu Tabel 1 sebagai berikut.

Tabel 1 Metode Pemecahan Masalah

\begin{tabular}{|c|c|c|c|}
\hline Solusi & Metode & Materi & Penyaji \\
\hline POC & $\begin{array}{l}\text { Diskusi } \\
\text { Presentasi } \\
\text { Tanya Jawab }\end{array}$ & $\begin{array}{l}\text { Analisis permasalahan } \\
\text { lingkungan sekitar } \\
\text { sekolah } \\
\text { Konsep tentang EM4 } \\
\text { dan Pupuk Organik Cair: } \\
\text { - Analisa bahan } \\
\quad \text { yang bisa } \\
\text { digunakan } \\
\text { - Proses pembuatan } \\
\text { EM4 } \\
\text { Proses } \\
\text { Pembuatan pupuk }\end{array}$ & $\begin{array}{l}\text { Tim } \\
\text { Pengabdian }\end{array}$ \\
\hline
\end{tabular}




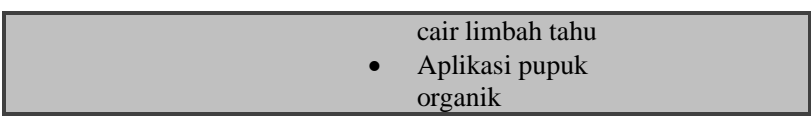

\begin{tabular}{|llll|}
\hline Solusi & Metode & Materi & Penyaji \\
\hline POC & $\begin{array}{l}\text { Pendampingan } \\
\text { pelatihan }\end{array}$ & $\begin{array}{l}\text { Pendampingan } \\
\text { pembuatan EM4 }\end{array}$ & $\begin{array}{l}\text { Tim } \\
\text { Pengabdian }\end{array}$ \\
\hline POC & $\begin{array}{l}\text { Pendampingan } \\
\text { pelatihan }\end{array}$ & $\begin{array}{l}\text { Pendampingan } \\
\text { pembuatan pupuk } \\
\text { organik cair } \\
\text { (POC) }\end{array}$ & $\begin{array}{l}\text { Tim } \\
\text { Pengabdian }\end{array}$ \\
\hline
\end{tabular}

\section{HASIL DAN LUARAN YANG DICAPAI}

Kegiatan PkM telah dilaksanakan di SMAN 08 Mataram, dengan tema "Pelatihan pembuatan pupuk organik cair limbah tahu bagi guru dan siswa SMAN 08 Mataram". Kegiatan ini bertujuan untuk meningkatkan kemampuan guru dan siswa dalam mengatasi permasalahan lingkungan yang diakibatkan oleh limbah organik. Pendidikan yang dibutahkan diera milinium ini adalah pendidikan yang lebih menekankan pada keterampilan porses yang dapat melahirkan siswa yang kereatif dan memiliki keterampilan berfikir tingkat tinggi. Pelatihan pembuatan pupuk organik cair ini adalah salah satu cara meningkatkan kreativitas guru dan siswa dalam menjawab permasalahan lingkungan.

Tahap awal kegiatan ini adalah observasi lingkungan sekolah selama 1 hari. Selanjutnya melihat ketersedian bahan yang dibutuhkan untuk pembuatan EM4. Kegiatan yang dilakukan pada tahap ini adalah mengajak guru dan siswa lebih peduli terhadap lingkungan serta mampu mengatasi permasalahan lingkungan. Selanjutnya guru dan siswa dikenalkan bahan-bahan yang ada disekitar lingkungan yang dapat dijadikan sebagai EM4.

Kegiatan pembuatan POC dilaksanakan selama satu bulan terhitung mulai tanggal 05 juni 2021 sampai dengan 05 juli 2021. Adapun hasil kegiatan pembuatan POC seperti disajikan pada Tabel 2 sebagai berikut.

Tabel 2. Hasil Pelaksanaan IST.

\begin{tabular}{|c|c|c|c|c|}
\hline No & Materi & $\begin{array}{l}\text { Hasil yang } \\
\text { dicapai }\end{array}$ & $\begin{array}{l}\text { Porsentase } \\
\text { peningkatan } \\
\text { pemahaman }\end{array}$ & $\begin{array}{c}\text { Kelemahan } \\
\text { dan } \\
\text { tantangan } \\
\text { Guru }\end{array}$ \\
\hline 1. & $\begin{array}{l}\text { Analisis } \\
\text { permasalahan } \\
\text { Lingkungan } \\
\text { disekitar }\end{array}$ & $\begin{array}{l}\text { - Guru } \\
\text { dan } \\
\text { siswa } \\
\text { sangat }\end{array}$ & $\begin{array}{l}50 \% \text { guru } \\
\text { dapat } \\
\text { menganalisis } \\
\text { permasalahan }\end{array}$ & $\begin{array}{l}\text { - Guru } \\
\text { kurang } \\
\text { memahami } \\
\text { teknik }\end{array}$ \\
\hline
\end{tabular}

\begin{tabular}{|c|c|c|c|c|}
\hline & Sekolah & $\begin{array}{l}\text { tertarik } \\
\text { belajar } \\
\text { langsung } \\
\text { dari } \\
\text { lingkung } \\
\text { an. } \\
\text { - Sebagia } \\
\text { n besar } \\
\text { guru } \\
\text { masih } \\
\text { belum } \\
\text { memaha } \\
\text { mi } \\
\text { teknik } \\
\text { pengola } \\
\text { han } \\
\text { limbah } \\
\text { organik. } \\
\text { - Pembela } \\
\text { jaran } \\
\text { pembuat } \\
\text { an } \\
\text { pupuk } \\
\text { sangat } \\
\text { menyena } \\
\text { ngkan } \\
\text { bagi } \\
\text { guru dan } \\
\text { siswa } \\
\text { karena } \\
\text { sangat } \\
\text { sesuai } \\
\text { dengan } \\
\text { kondisi } \\
\text { lingkung } \\
\text { an } \\
\text { sekitar } \\
\text { guru dan } \\
\text { siswa }\end{array}$ & $\begin{array}{l}\text { lingkungan } \\
\text { sekitar } \\
\text { sekolah. }\end{array}$ & $\begin{array}{l}\text { pengolahan } \\
\text { limbah. } \\
\text { - Guru } \\
\text { kurang } \\
\text { memahari } \\
\text { bahan- } \\
\text { bahan yang } \\
\text { ada } \\
\text { dilingkunga } \\
\text { n sekitar } \\
\text { yang dapat } \\
\text { digunakan } \\
\text { dalam } \\
\text { pembuatan } \\
\text { EM4 } \\
\text { - Guru masih } \\
\text { kesulitan } \\
\text { dalam } \\
\text { menentukan } \\
\text { alat yang } \\
\text { dapat } \\
\text { digunakan } \\
\text { untuk } \\
\text { pembuatan } \\
\text { POC }\end{array}$ \\
\hline 2 & Konsep EM4 & $\begin{array}{l}\text { - Guru } \\
\text { EM4 } \\
\text { tetapi } \\
\text { belum } \\
\text { bisa } \\
\text { membua } \\
\text { t dari } \\
\text { bahan- } \\
\text { bahan } \\
\text { yang ada } \\
\text { dilingku } \\
\text { ngan } \\
\text { sekitar. }\end{array}$ & $\begin{array}{l}25 \% \text { guru } \\
\text { memahami } \\
\text { EM4 }\end{array}$ & $\begin{array}{l}\text { Literasi yang } \\
\text { masih kurang } \\
\text { menyebabkan } \\
\text { guru belum } \\
\text { dapat } \\
\text { memanfaatkan } \\
\text { bahan yang } \\
\text { ada } \\
\text { dilingkungan } \\
\text { menjadi EM4 }\end{array}$ \\
\hline 3 & $\begin{array}{l}\text { Konsep } \\
\text { tentang POC }\end{array}$ & $\begin{array}{l}\text { Sebagain } \\
\text { Besar guru } \\
\text { memahari } \\
\text { tentang } \\
\text { pupuk } \\
\text { organik } \\
\text { tetapi } \\
\text { pembutan } \\
\text { pupuk } \\
\text { organik } \\
\text { dari limbah } \\
\text { tahu belum } \\
\text { pernah } \\
\text { dilakukan. } \\
\text { Guru-guru } \\
\text { hanya } \\
\text { melakukan } \\
\text { pengompos } \\
\text { an dari } \\
\text { limbah } \\
\text { organik } \\
\text { yang ada } \\
\text { dihalaman } \\
\end{array}$ & $\begin{array}{l}70 \% \text { guru } \\
\text { dapat } \\
\text { memahami } \\
\text { cara } \\
\text { pengomposan. }\end{array}$ & $\begin{array}{l}\text { Literasi teknik } \\
\text { pembuatan } \\
\text { pupuk organik } \\
\text { masih } \\
\text { terbatas. }\end{array}$ \\
\hline
\end{tabular}




\begin{tabular}{|c|c|c|c|c|}
\hline & & $\begin{array}{l}\text { sekolah } \\
\text { yang } \\
\text { berasal dari } \\
\text { daun dan } \\
\text { batang } \\
\text { pohon } \\
\text { dilingkung } \\
\text { an sekolah } \\
\end{array}$ & & \\
\hline 4 & $\begin{array}{l}\text { Pembuatan } \\
\text { EM4 }\end{array}$ & $\begin{array}{l}\text { Guru dapat } \\
\text { membuat } \\
\text { EM4 } \\
\text { berdasarka } \\
\text { n prosedur } \\
\text { yang telah } \\
\text { ditentukan }\end{array}$ & $\begin{array}{l}85 \% \text { guru } \\
\text { Membuat } \\
\text { EM4. }\end{array}$ & $\begin{array}{l}\text { Masih ada } \\
\text { sebagian guru } \\
\text { yang } \\
\text { keterampilan } \\
\text { proses sain } \\
\text { masih rendah }\end{array}$ \\
\hline 5 & $\begin{array}{l}\text { Pembuatan } \\
\text { POC }\end{array}$ & $\begin{array}{l}\text { Guru dapat } \\
\text { membuat } \\
\text { POC } \\
\text { berdasarka } \\
\text { n prosedur } \\
\text { yang telah } \\
\text { ditentukan }\end{array}$ & $\begin{array}{l}85 \% \text { guru } \\
\text { Membuat } \\
\text { POC. }\end{array}$ & $\begin{array}{l}\text { Masih ada } \\
\text { sebagian guru } \\
\text { yang } \\
\text { keterampilan } \\
\text { proses sain } \\
\text { masih rendah }\end{array}$ \\
\hline
\end{tabular}

Berdasarkan kegitan di atas pelatihan pembuatan pupuk memberikan dampak yang sigbifikan terhadap pengayaan sumber belajar IPA bagi guru dan siswa. Pembuatan EM4 dan POC menjadi salah satu cara bagaimana guru dan siswa melihat masalah dan mencari solusi dari masalah lingkungan yang dihadap

\section{Luaran yang Telah Dicapai}

Luaran yang telah dicapai dalam kegiatan pengabdian ini seperti tercantum pada Tabel 3 sebagai berikut.

Tabel 3. Capaian Luaran Kegiatan Pengabdian kepada Masyarakat

\begin{tabular}{lll} 
No & Jenis Luaran & Keterangan \\
1. & $\begin{array}{l}\text { Produk, berupa EM4 } \\
\text { yang dibuat dari } \\
\text { bahan-bahan yang } \\
\text { ada dilingkungan }\end{array}$ & $\begin{array}{l}\text { Tercapai, dengan ada } \\
\text { produk setelah hari ke 14. }\end{array}$ \\
sekitar sekolah & $\begin{array}{l}\text { Produk, berupa POC } \\
\text { dari limbah cair tahu }\end{array}$ & $\begin{array}{l}\text { Tercapai, dengan ada } \\
\text { produk setelah hari ke 14 } \\
\text { dari penambahan EM4. }\end{array}$ \\
\hline
\end{tabular}

Berdasarkan luaran capaian yang dihasilkan oleh guru sesuai Tabel 4 tersebut menunjukkan bahwa pelaksanaan kegiatan pengabdian kepada masyarakat dinyatakan berlangsung dengan baik dan mencapai target atau tujuan sesuai luaran yang diharapkan.

\section{KESIMPULAN}

Kesimpulan Kegiatan pengabdian kepada masyarakat yang melibatkan guru guru dan siswa SMAN 08 Mataram telah berjalan dengan baik sesuai dengan perencanaan, terbukti dengan dihasilkannya produk EM4 dan POC.

\section{SARAN}

Diperlukan analisa lebih lanjut tentang kualitas POC dan efektivitasnya bagi tanaman khususnya sayur.

\section{DAFTAR PUSTAKA}

Makiyah, Mujiatul. 2011. Analisis Kadar N, $P$ dan K Pada Pupuk Cair Limbah Tahu Dengan Penambahan Tanaman Matahari Meksiko (Thitonia)

Nasir, M., Saputro, E.P., \& Handayani, S.. 2015. Manajemen Pengelolaan Limbah Industri. BENEFIT: Jurnal Manajemen dan Bisnis. 19 (2): 143149.

Sato Abas, Priyo Utomo, \& Hafid Sustantyo Bima Abineri. 2015. Pengolahan Limbah Tahu Secara AnaerobikAerobik Kontinyu. Surabaya: Jurusan Teknik Kimia, Institut Teknologi Adhi Tama.

Sudaryati, N. L. G. I. W. Kasa \& I. W. B. Suyasa. 2007. Pemanfaatan Sedimen Perairan Tercemar sebagai Bahan Lumpur Aktif dalam Pengolahan Limbah Cair Industri Tahu. ECOTROPIC. 3(1): 21-29.

Tonni Agustiono Kurniawan, ab Waihung Lo,a G. Chana and Mika E. T. Sillanp. 2010. Biological processes for treatment of landfill leachate. $J$. Environ. Monit., 2010, 12, 2032-2047 